\title{
The effect of a combined oral calcium and vitamin D supplement for treating mild to moderate vitamin D deficiency in postmenopausal women
}

\author{
Terry Golombick \\ Terry Diamond \\ Department of Endocrinology, \\ St George Hospital, Kogarah, Sydney, \\ NSW, Australia
}

Objective: To evaluate the efficacy of a combined calcium and vitamin D (Ca-D3) supplement for vitamin D deficiency in a small group of postmenopausal women.

Methods: A prospective open label 3 month-study.

Participants: 23 postmenopausal women (mean age $61.2 \mathrm{yrs}$ ) with vitamin D deficiency were given a combined oral Ca-D3 supplement called “Osteoblast". The supplement comprises $500 \mathrm{mg}$ elemental calcium and 500 IU of cholecalciferol. The dosing regimen comprised a loading dose of $1000 \mathrm{IU}$ of cholecalciferol per day for one month (two tablets) and thereafter a maintenance dose of $500 \mathrm{IU}$ of cholecalciferol per day for 2 months (one tablet).

Outcome measure: Serum was collected for calcium, 25 hydroxyvitamin D3 (25OHD3), and PTH measurements, as well as early morning 2-hour urine calcium/creatinine excretion index (Uca/creat). Specimens were collected at baseline and after 3 months of therapy. Data are reported as mean \pm 1 standard error and $95 \%$ confidence intervals.

Results: Data was available for the 21 subjects who completed the study. Two subjects (9\%) withdrew because of gastrointestinal intolerance. There were 3 subjects with moderate (12.5-24 $\mathrm{nmol} / \mathrm{L}$ ) and 18 with mild (25-49 nmol/L) vitamin D deficiency. Ten subjects (48\%) had secondary hyperparathyroidism. Following the oral Ca-D3 combination, serum 25OHD3 levels normalised in all subjects with 18 (86\%) subjects achieving values of greater than $70 \mathrm{nmol} / \mathrm{L}$. Serum 25OHD3 levels increased from $36(31-41)$ to 91 (79-102) nmol/L ( $p=0.0001)$, increasing by an average of $152 \%$ over the 3 -month period. There was a corresponding $38 \%$ decrease in serum PTH concentrations at 3 months $(5.1+0.6 \mathrm{pmol} / \mathrm{L})$, compared with baseline $(8.0+1$ $\mathrm{pmol} / \mathrm{L})(\mathrm{p}=0.001)$. No subject developed hypercalcemia, but an elevated Uca/creat excretion index occurred in one subjects.

Conclusions: A combined oral Ca-D3 product (Osteoblast) is effective for treating vitamin D deficiency and is adequately tolerated.

\section{Introduction}

There is a resurgence of vitamin D deficiency in the developed world, even in "sunny" Australia (Diamond et al 2005). The clinical spectrum ranges from mild to severe deficiency, with serum 25-hydroxyvitamin D (25OHD) levels less than $25 \mathrm{nmol} / \mathrm{L}$. The prevalence of vitamin D deficiency among elderly people living in residential homes has been estimated to be at least 50\% (Flicker et al 2003). Other high risk groups include ethnic populations from the Horn of Africa, India, and Pakistan, and patients with gastrointestinal malabsorption syndromes (Skull et al 2003; Diamond et al 2005). Vitamin D deficiency is frequently seen in women treated for osteoporosis (MORE study) (Ettinger et al 1999).

Vitamin D deficiency leads to hypocalcemia, secondary hyperparathyroidism, and increased bone turnover (Adams et al 1999; Leboff et al 1999). This may be associated with osteoporosis and osteofragility fractures, which occur due to reduction 
in bone strength superimposed on trauma such as a fall. A deficiency in skeletal and total body calcium is frequently part of the vitamin D deficiency syndrome. Calcium deficiency is insidious in its early stages and potentially irreversible in the latter, making preventative optimization the only successful pathway in all patients perceived to be at risk of calcium deficiency (Arthur 2007).

Calcium and vitamin D repletion can improve bone mineral density and reduce fracture risk in individuals with frank vitamin D deficiency. Moreover, calcium and vitamin D supplementation is often required as a necessary adjunct to all forms of anti-osteoporotic therapies. The current calcium requirements are 1-1.3 g/day for adults (Bryant et al 1999). The need for vitamin D supplementation is dependent on the serum 25 hydroxyvitamin $\mathrm{D}$ level, with values of greater than 60-70 nmol/L (Peacock et al 1985) considered for optimal bone health.

A number of "over the counter" calcium and vitamin D preparations are currently available for both the treatment and prevention of osteoporosis and vitamin D deficiency. The main Ca-D3 combination supplement currently available in Australia is Caltrate D which contains 200 IU of vitamin D3 combined with $600 \mathrm{mg}$ elemental calcium. Most other supplements contain either D3 or calcium in a single preparation. We therefore undertook an open-labelled prospective study assessing the role of "Osteoblast", a combined oral calcium carbonate $(500 \mathrm{mg})$ and cholecalciferol (500 IU) tablet as therapy for mild to moderate vitamin D deficiency (for full list of ingredients, and comparison with other products available on the market, please see Table 1).

\section{Method}

We conducted a prospective open-label 3 month study on 23 women (mean age 61.2 years) with vitamin $\mathrm{D}$ deficiency.
These women were given a combined oral Ca-D3 supplement called "Osteoblast". This preparation contains 500 IU cholecalciferol and $500 \mathrm{mg}$ elemental calcium as a carbonate salt. This combined high dose vitamin D supplement appeared ideal, not only for calcium supplementation but in addition, as therapy for vitamin D deficiency.

Consecutive women with postmenopausal osteoporosis who displayed biochemical evidence of vitamin $\mathrm{D}$ deficiency (serum 25-hydroxyvitamin D3 $<50 \mathrm{nmol} / \mathrm{L}$ ) presenting to the metabolic bone clinic at St George Hospital were recruited if they had no evidence of hypercalcemia (serum calcium $>2.65 \mathrm{mmol} / \mathrm{L}$ ), primary hyperparathyroidism, thyrotoxicosis, Paget's disease, malignancy, significant renal impairment (serum creatinine $>0.15 \mathrm{mmol} / \mathrm{l}$ ), or were currently receiving treatment with calcitriol or high-dose oral calcium supplements (1200 mg/day of elemental calcium). All gave informed consent and were administered 2 tablets of osteoblast daily (morning or evening) for one month and thereafter one tablet daily for 2 months. The study was conducted during winter. Whilst a diary estimating sunlight exposure was not requested, patients were advised not to change their sun exposure pattern. A strict dietary calcium recall was not undertaken. Patients were advised not to add any vitamin supplements to their diet or to adjust their dietary calcium intake during the study.

Participants were evaluated by biochemical assessments at baseline and after 3 months of therapy. Since this was a pilot study, the trial was not registered. However, the study was performed according to National Health and Medical Research Council guidelines.

Serum (fasting) and urinary (2-hour) calcium, urea and creatinine levels were determined by autoanalyser methods. Hypercalcemia was defined as a serum calcium

Table I "Over the counter" calcium and vitamin D preparations available

\begin{tabular}{|c|c|c|c|c|c|c|c|}
\hline & $\begin{array}{l}\text { Caltrate } \\
\text { plus }\end{array}$ & $\begin{array}{l}\text { Swisse } \\
\text { calverv } \\
\text { M3 }\end{array}$ & $\begin{array}{l}\text { Blackmores } \\
\text { bio calcium }\end{array}$ & $\begin{array}{l}\text { Nature's own } \\
\text { calcium and } \\
\text { magnesium } \\
\text { with vitamin D3 }\end{array}$ & $\begin{array}{l}\text { NutraLife super } \\
\text { calcium } \\
\text { complete }\end{array}$ & $\begin{array}{l}\text { Blooms } \\
\text { osteo } \\
\text { blast }\end{array}$ & RDIs and Als \\
\hline Calcium & $600 \mathrm{mg}$ & $305 \mathrm{mg}$ & $350 \mathrm{mg}$ & $250 \mathrm{mg}$ & $270 \mathrm{mg}$ & 500 & $1000-1300 \mathrm{mg}$ \\
\hline Vitamin D3 & 200 iu & 480 iu & $100 \mathrm{iu}$ & 200 iu & 100 iu & 500 iu & $200-600$ iu \\
\hline Magnesium & $50 \mathrm{mg}$ & 300 mg & & $50 \mathrm{mg}$ & $250 \mathrm{mg}$ & $110 \mathrm{mg}$ & $310-420 \mathrm{mg}$ \\
\hline Manganese & $1.8 \mathrm{mg}$ & $2.5 \mathrm{mg}$ & & & I. mg & $2.5 \mathrm{mg}$ & $5-55 \mathrm{mg}$ \\
\hline Zinc & $7.5 \mathrm{mg}$ & $12.15 \mathrm{mg}$ & & & $0.5 \mathrm{mg}$ & $5 \mathrm{mg}$ & $8-14 \mathrm{mg}$ \\
\hline Copper & $\mathrm{I} \mathrm{mg}$ & $35 \mathrm{mcg}$ & & & & $\mathrm{I} \mathrm{mg}$ & $1.2-1 / 7 \mathrm{mg}$ \\
\hline Vitamin K & & & & & $2.2 \mathrm{mcg}$ & $23 \mathrm{mcg}$ & $60-70 \mathrm{mcg}$ \\
\hline $\begin{array}{l}\text { Betacarotene } \\
\text { (as Retinol equivalents) }\end{array}$ & & & & & & $300 \mathrm{mcg}$ & $700-1100 \mathrm{mcg}$ \\
\hline Boron & & & & & $0.4 \mathrm{mg}$ & $\mathrm{I} \mathrm{mg}$ & - \\
\hline Silicon & & & & & & $7 \mathrm{mg}$ & - \\
\hline
\end{tabular}


concentration higher than $2.65 \mathrm{mmol} / \mathrm{L}$. Two-hour urine calcium/creatinine excretion indices were used to determine hypercalciuria. A urine calcium/creatinine excretion index over 0.60 was considered abnormal.

All serum 25OHD3 specimens were measured using the LIAISON $25 \mathrm{OH}$ Vitamin D TOTAL assay (DiaSorin Inc, Stillwater, USA). Specificity for $25 \mathrm{OHD} 3$ was $100 \%$, and intra-assay precision was $5.3 \%$ at $26.5 \mathrm{nmol} / \mathrm{L}$ and $6.1 \%$ at $151 \mathrm{nmol} / \mathrm{L}$.

Serum levels of intact parathyroid hormone (PTH) were measured by chemiluminometric technology (Advia Centaur Assay, Bayer Corp, USA). The intra-assay precision was $5.2 \%$ at $4.3 \mathrm{pmol} / \mathrm{L}$ and $3.4 \%$ at $23.7 \mathrm{pmol} / \mathrm{L}$. Hyperparathyroidism was defined as a serum PTH level over $7.5 \mathrm{pmol} / \mathrm{L}$.

\section{Statistical analysis}

Data are presented as mean \pm 1 standard error and $95 \%$ confidence intervals. Group mean values were compared by student t-test. Significance was considered if p-value $<0.05$.

\section{Results}

Data was available for the 21 subjects who completed the study (Table 2). Two subjects ( $9 \%$ ) withdrew because of gastrointestinal intolerance. There were 3 subjects with moderate (12.5-24 nmol/L) and 18 with mild (25-49 nmol/L) vitamin $\mathrm{D}$ deficiency. Ten subjects (48\%) had secondary hyperparathyroidism. Following the oral Ca-D3 combination, serum $25 \mathrm{OHD} 3$ levels normalized in all subjects with $18(86 \%)$ subjects achieving values of greater than $70 \mathrm{nmol} / \mathrm{L}$. Serum 25OHD3 levels increased from 36 (31-41) to 91 (79-102) $\mathrm{nmol} / \mathrm{L}(\mathrm{p}=0.0001)$, increasing by an average of $152 \%$ over the 3-month period. There was a corresponding 38\% decrease in serum PTH concentrations at 3 months $(5.1+0.6 \mathrm{pmol} / \mathrm{L})$, compared with baseline $(8.0+1 \mathrm{pmol} / \mathrm{L})(\mathrm{p}=0.001)$. No subject developed hypercalcemia, but an elevated Uca/creat excretion index occurred in one subject.

\section{Discussion}

The major source of vitamin D in humans is sunlight. In the absence of adequate sunlight exposure, supplementation becomes important. Data suggests that serum 25OHD3 of at least $60-70 \mathrm{nmol} / \mathrm{L}$ or greater is required for optimum bone health and is protective against secondary hyperparathyroidism and decreased bone density (Peacock et al 1985). In Australia, the National Health and Medical Research Council recommends a daily oral intake of at least 400 IU vitamin $\mathrm{D}$ for those who are at risk of vitamin $\mathrm{D}$ deficiency (NHMRC 1991).

Vitamin D repletion in individuals presenting with vitamin $\mathrm{D}$ deficiency has been shown to have a positive effect on bone biology, resulting in mineralization of osteoid, increases in bone mineral density measurements and reduced fracture rates (Diamond et al 2005). In a landmark trial in elderly institutionalized women, 800 IU of oral vitamin D3 with calcium supplements resulted in significant reduction in both nonvertebral (3.8\%) and hip (2\%) fractures, and a significant improvement in femoral neck bone density after 36 months of therapy (Chapuy et al 1992). A report of bone histomorphometric changes in 28 patients with osteomalacia treated with various vitamin D preparations and calcium showed an $80 \%$ reduction in osteoid volume and an increase in mineralized bone volume in cortical (+7.5\%) and trabecular bone (+40\%) after therapy (Parfitt et al 1985).

Calcium deficiency can be secondary to vitamin D deficiency. Vitamin D facilitates calcium absorption through the small intestine. In addition to vitamin D deficiency being common, a Melbourne study of 1045 women aged 20-92 years in 2000 revealed that approximately $76 \%$ consumed less than the RDI for calcium and an additional 14\%

Table 2 Study results

\begin{tabular}{|c|c|c|c|c|}
\hline Variable & Mean & SEM & $\begin{array}{l}95 \% \mathrm{Cl} \\
\text { range }\end{array}$ & p-value \\
\hline Age (years) & 61.2 & 3.2 & $27-86$ & \\
\hline (S) $\mathrm{Ca}^{\mathrm{a}}(\mathrm{mmol} / \mathrm{L})$ & 2.29 & 0.02 & $2.24-2.34$ & \\
\hline (S) $\mathrm{Ca}^{\mathrm{b}}(\mathrm{mmol} / \mathrm{L})$ & 2.34 & 0.02 & $2.29-2.39$ & $\mathrm{P}=0.05 \mathrm{vs}$ basal \\
\hline (S) $\mathrm{PTH}^{\mathrm{a}}(\mathrm{pmol} / \mathrm{L})$ & 8.0 & 1.0 & $5.8-10.2$ & \\
\hline (S) $\mathrm{PTH}^{\mathrm{b}}(\mathrm{pmol} / \mathrm{L})$ & 5.1 & 0.6 & $3.8-6.3$ & $\mathrm{P}=0.006 \mathrm{vs}$ basal \\
\hline (S) $25 \mathrm{OHD}^{\mathrm{a}}(\mathrm{nmol} / \mathrm{L})$ & 36.1 & 2.2 & $3|-4|$ & \\
\hline (S) $25 \mathrm{OHD}^{\mathrm{b}}(\mathrm{nmol} / \mathrm{L})$ & 90.6 & 5.6 & $79-102$ & $\mathrm{P}=0.000 \mathrm{I}$ vs basal \\
\hline U Ca/Creat (Mmol/Mmol) & 0.28 & 0.06 & $0.17-0.39$ & \\
\hline
\end{tabular}

Abbreviations: a, before; $b$, after. 
demonstrated a grossly inadequate intake of $<300 \mathrm{mg} /$ day (Arthur 2007). These figures appear consistent with the findings of the 1995 National Nutrition Survey and larger US studies. Calcium supplementation is effective in preventing further deterioration in bone quality and reducing fracture rates. It cannot, however, reverse the condition.

The accepted paradigm for effective treatment of vitamin D deficiency is correction of the vitamin D deficiency with vitamin D supplements together with calcium. These are taken together with anti-osteoporosis medications when indicated.

In Australia a number of combined Ca-D3 preps are available over the counter. Table 1 compares some of the main products currently available in the marketplace.

Our study assessed the role of "Osteoblast", a combination oral tablet with $500 \mathrm{mg}$ calcium and 500 IU cholecalciferol, as therapy for mild to moderate vitamin D deficiency. Our results showed a significant improvement in vitamin D status accompanied by a significant decrease in PTH levels, proving efficacy in the treatment of this condition. Data by Vieth and colleagues (2004) has shown that supplementation with cholecalciferol 600 IU daily for 2-6 months increased serum 25 hydroxyvitamin D levels from 49 to $79 \mathrm{nmol} / \mathrm{L}$. These data are similar to our findings. Based on our results, we are recommending adequate $\mathrm{Ca}-\mathrm{D} 3$ for bone health as part of therapy for postmenopausal osteoporosis, not as therapy for severe vitamin D deficiency.

\section{Conclusion}

A combined oral Ca-D3 product is effective for treating vitamin $\mathrm{D}$ deficiency and is adequately tolerated.

\section{References}

Adams JS, Kantorovich V, Wu C, et al. 1999. Resolution of vitamin D insufficiency in osteoporotic patients results in rapid recovery of bone mineral density. J Clin Endocrinol Metab, 84:2729-30.

Arthur R. 2007. Calcium. J Compl Med, 6:46-54.

Bryant RJ, Cadogan J, Weaver CM. 1999. The new dietary reference intakes for calcium: implications for osteoporosis. $J$ Am Coll Nutr, 18(5 Suppl):406S-412S.

Chapuy MC, Arlot ME, Duboeuf F, et al. 1992. Vitamin D3 and calcium to prevent hip fractures in elderly women. $N$ Engl J Med, 327:1637-42.

Diamond TH, Eisman JA, Mason RS, et al. 2005. Vitamin D and adult bone health in Australia and New Zealand: a position statement. Med $J$ Aust, 182:281-5.

Diamond TH, Ho KW, Rohl PG, et al. 2005. Annual intramuscular injection of a megadose of cholecalciferol for treatment of vitamin D deficiency: efficacy and safety data. MJA, 183:10-12.

Ettinger B, Black DM, Mitlak BH, et al. 1999. Reduction of Vertebral fracture risk in postmenopausal women with osteoporosis treated with Raloxifene. JAMA, 282:637.

Flicker L, Mead K, MacInnis RJ, et al. 2003. Serum vitamin D and falls in older women in residential care in Australia. $J$ Am Geriatr Soc, 51:1533-8.

Leboff MS, Kohlmeimer L, Hurwitz S, et al. 1999. Occult vitamin D deficiency in postmenopausal US women with acute hip fractures. JAMA, 281:1505-11.

[NHMRC] National Health and Medical Research Council. 1991. Recommended dietary intakes for use in Australia. Canberra: AGPS.

Parfitt AM, Rao DS, Stanciu J, et al. 1985. Irreversible bone loss in osteomalacia: comparison of radial photon absorptiometry with iliac bone histomorphometry during treatment. J Clin Invest, 76:2403-12.

Peacock M, Selby PL, Francis RM, et al. 1985. Vitamin D deficiency, insufficiency, sufficiency and intoxication, what do they mean? In: Schaefer NA, Grigoletti MG, Herrath DV eds. Sixth workshop on vitamin D. Berlin: DeGruyter, pp 569-70.

Skull SA, Ngeow JYY, Biggs BA, et al. 2003. Vitamin D deficiency is common and unrecognised among recently arrived adult immigrants from the Horn of Africa. Int Med J, 33:47-51.

Vieth R, Kimball S, Hu A, et al. 2004. Randomized comparison of the effects of the vitamin D3 adequate intake versus $100 \mathrm{mcg}$ per day on biochemical responses and the wellbeing of patients. Nutrition J, 3:8. 